\title{
Financial Inclusion and Tax Revenue: Evidence From Europe
}

\author{
Bassam Al-Own $^{1} \&$ Tareq Bani-Khalid ${ }^{2}$ \\ ${ }^{1}$ Finance \& Banking Department, $\mathrm{Al}$ al- Bayt University, Mafraq, Jordan \\ ${ }^{2}$ Accounting Department, Al al- Bayt University, Mafraq, Jordan \\ Correspondence: Bassam Al-Own, Finance \& Banking Department, Al al- Bayt University, Mafraq, Jordan. \\ Received: September 30, 2020 \\ Accepted: November 4, 2020 \\ Online Published: January 11, 2021 \\ doi:10.5430/ijfr.v12n2p27 \\ URL: https://doi.org/10.5430/ijfr.v12n2p27
}

\begin{abstract}
This paper aimed to investigate the relationship between financial inclusion and tax revenue using measures from the Global Findex database for a sample of 28 European countries between 2011- 2017. The data were analysed using panel data methodology. The number of people who are financially included in this observed period might increase over time, which would create more income and in turn lead to higher tax contributions to the government. We found strong evidence to suggest that financial inclusion represents one of the determinants of tax revenue in European countries. Results of the analysis show positive and significant impact of financial inclusion as measured by Bank account $(\%$ of age +15$)$ and credit card ownership (\% age 15+) on tax revenues measures. The results are robust using several sources of taxation. The findings suggest that higher financial inclusion is associated with more tax revenue. These results should be of great interest to regulators and policymakers to take advantage of the developments on financial inclusion.
\end{abstract}

Keywords: financial inclusion, tax revenue, bank account, credit card, policymakers, financial system, panel data, taxation

JEL Classification: G20, E62, H20

\section{Introduction}

Over the last decade, the topic of financial inclusion has generated a great deal of interest with academics and policy makers and recently has recognised as a primary and strategic pillar that enhance development in many countries (Sarma and Pais, 2011).

According to the World Bank report (2010), almost half of the people around the world live financially excluded. Between 2011 and 2017, a dramatic global rise on financial inclusion occurred. The 2017 Global Findex database reports that since 2011, more than one billion adults have become financially included by obtaining formal account in a financial institution or through a mobile money service.

Financial inclusion is classified as a central objective among financial regulatory and researchers for several reasons. For example, financial inclusion is taken as primary instrument used to achieve higher economic development and to encourage innovations (Yawe and Prabhu, 2015; Demirguc-Kunt, Klapper and Singer, 2017). Further, financial inclusion can help the government to obtain additional financial resources, increase investment opportunities, and reduce budget deficit (Zachosova, Babina, and Zanora, 2018). Financial inclusion can also help governments in its strategy for poverty alleviation (Chibba, 2009). Moreover, financial inclusion contribute to higher macroeconomic and bank stability after the recent global financial crisis (Cull, Demirguc-Kunt, and Lyman, 2012; Ozili, 2020). For these reasons, financial inclusion and access to financial services has become a popular topic with academics and policy makers alike.

Expanding access to finance to poor individuals and informal business owners could positively influence economic activity (Bruhn and Love, 2014). The mechanism of financial inclusion leads to more income earning opportunities and reduce poverty (Zhang and Posso, 2019). Accordingly, when the accessibility to financial institutions increases and when peoples' income increases, it is expected that their tax payments to the government will also increase (Nnyanzi, Bbale, and Sendi, 2018; Oz-Yalaman, 2019). This provides an opportunity for the government and policymakers to benefit from increased income by raising annual tax revenues. 
Generally, the aim of financial inclusion policies is to reduce financial exclusion and encourage people to access and use formal financial services to promote economic growth and financial development (Sharma, 2016; Allen, Demirguc-Kunt, Klapper, and Peria, 2016).

On one hand, encouraging people to use formal financial services allows them to make financial transactions more efficiently and safely (Demirguc-Kunt et al., 2017). Moreover, greater inclusion to the formal financial system increases the chance to facilitate investments and increase business opportunities, which lead to more tax revenue to support economic growth. On the other hand, inactive individuals create challenges for regulators and policymakers because this can negatively affect the size of financial transactions in the financial system, thereby reducing the revenue to financial sector and the tax revenue, ultimately affecting economic growth (Ozili, 2020). Thus, increasing financial inclusion level can be translated to more financial activity which increase the revenue to financial sector, and eventually can raise the tax revenue to the government (Xu, 2019; Ozili, 2020). Policymakers and regulators should be concerned about taking advantage of the increase in financial inclusion activities and the possible associated increase in income by increasing tax revenues.

The objective of this paper is to examine financial inclusion in European countries by investigating the linkage between financial inclusion and tax revenues using the World Bank Global Findex Database between 2011 and 2017. The rest of the paper is structured as follows. In Section 2, existing literature will be reviewed. Section 3 details the research methodology, data, and sample. The empirical results and future recommendation are all presented in Section 4. Finally, Section 5 provides the research conclusion.

\section{Literature Review}

The study of financial inclusion is important for society as it represents one of the essential government policy tools (Ozili, 2020). Financial inclusion play evident role in improving living standard of the poor, increasing income equality, and enhancing the of the financial markets (Morgan and Pontines, 2014; Musau, Muathe, and Mwangi, 2018; Park and Mercado, 2015; Kim, 2016; Neaime and Gaysset, 2018). Prior studies have highlighted that financial inclusion has positive impact on economic growth and play key role in bridging the gap between poor and rich individuals (e.g. Kim, 2016; Iqbal and Sami, 2017).

According to Sarma and Pais, (2011), "financial inclusion refers to a process that ensures the ease of access, availability and usage of the formal financial system for all members of an economy". It also can be introduced as the situation where individuals or firms have the ability to access to useful and affordable financial sector's products and services that meet their needs (World Bank, 2017).

In empirical literature, different themes relevant to financial inclusion have been investigated, and it has been shown that financial inclusion has the potential to improve economic growth and financial stability. For example, at the regional level, Kim (2016) investigated the impact of financial inclusion on economic growth using cross-sectional data for 40 countries between 2004 and 2011. The results revealed that a decrease in income inequality through financial inclusion induces higher economic growth. Furthermore, Kim, Yu, and Hassan (2018) also provide empirical evidence of positive impact of financial inclusion on economic growth using a sample form Organisation of Islamic Cooperation (OIC) countries.

At the country level, Mohan (2006) showed in India financial inclusion activities strengthen financial deepening by providing more resources to meet the increased demand for financial services. In addition, Sharma (2016) also documents evidences of positive relationship between economic growth in India and financial inclusion measures. In contrast, according to Okoye, Erin, and Modebe (2017), financial inclusion (measured using credit delivery to private sector) in Nigeria has positive impact on poverty reduction; however, it has not largely improved economic growth.

Empirical studies have also explored the how financial inclusion strategies influence financial stability. For instance, Neaime and Gaysset (2018) rely on a sample from MENA region to assess the effect of financial inclusion on financial stability for the period 2002-2015. They conclude that although financial inclusion has not related to poverty, it enhances financial stability. In contrast, Li (2018) show that poor people choice to access financial resources enhances their wealth and is not derived by 'keeping up with the Joneses' incentive (Note 1). Taking an international sample of that consist of 2600 banks in 86 countries between 2004 and 2012, Ahamed and Mallick (2019) provided evidence that more financial inclusion contributes to higher banking stability increases.

While literature emphasises the importance of globally initiatives and governments' efforts to enhance financial inclusion, and presents empirical evidences on the positive effect of financial inclusion in enhancing economic growth, increasing financial stability, and bringing additional income into the financial markets, very little attention has been devoted to investigating whether such policy tools have become a channel of taxation for governments. 
Prior empirical studies on the impact of financial inclusion on tax revenue are scarce (Maherali, 2017; Oz-Yalaman, 2019). One of the few empirical attempts to examine this impact on tax revenue is by Oz-Yalaman (2019). She relied on a sample comprising 137 countries over the period 2011-2017 to investigate whether financial inclusion determines tax revenues. The results displayed significant positive association between different tax revenue measures and financial inclusion. Thus, according to Oz-Yalaman's data, as people become more financially included, their income is expected to increase, leading to higher tax gains for governments.

In addition, Maherali (2017) used various global databases to examine the impact of financial inclusion and digital payments on government tax revenues for countries around the world. The results indicate that both financial inclusion and digital payment have positive impact on tax revenue. Furthermore, Mitchell and Scott (2019) demonstrated that financial inclusion in Argentina, Brazil and Chile led to higher value-added tax (VAT) collection from 2002 to 2015.

This paper adds to the existing literature on this topic by bridging a significant gap on empirical studies that analyse the impact of financial inclusion on taxation. While prior studies have used samples from countries around the world, there is no research conducted at either country level or regional level. This paper attempts to fill this gap and empirically present evidence at the regional level on how financial inclusion influences tax revenue using a sample from European countries.

The insights gained through this paper can also assist governments and regulators in gaining more explanations of the association between financial inclusion activities and tax revenue to help them in assessing the outcome of financial inclusion.

\section{Method}

This study will examine the impact of financial inclusion on tax revenue in European countries. The data used in this paper have been collected using the World Bank's Global Financial Inclusion (Global Findex) Database and International Monetary Funds' (IMF) Financial Access Survey Database. These databases provide consistent data and well-known international sources (Sarma and Pais, 2011). One of the main advantages of using these databases is that the standardised survey and questions used to collect the data from countries around the world make it easier to compare or pool the data across countries (Asuming, Osei-Agyei, and Mohammed, 2018). The Global Findex database has been published every three years since 2011, and the latest survey was conducted in 2017(Note 2). This research uses data for 28 European countries from 2011 to 2017 . The sample period was selected due to the availability of data.

Data specific to the financial inclusion variables include: Bank account $(\%$ of age +15$)$ and credit card ownership $(\%$ age $15+)$. For the dependent variable, which is tax revenue, the following four measures were used: tax revenue $(\%$ of GDP), taxes on income (\% of revenue), and individual income tax revenue (\% of GDP), and corporate income tax revenue (\% of GDP). Table 1 provides further details about the variables used in the empirical model, including the definition of each variable and the source of the data used to measure the variable. The European countries under investigation are: UK, Italy, Germany, France, Spain, Netherlands, Sweden, Finland, Ireland, Denmark, Belgium, Poland, Estonia, Bulgaria, Cyprus, Malta, Austria, Latvia, Croatia, Lithuania, Czech Republic, Hungary, Greece, Romania, Portugal, Luxembourg, Slovenia, and Slovak Republic.

Table 1. Variables definition and sources

\begin{tabular}{lllll}
\hline Type & Variable name & Code & Definition & Source \\
\hline $\begin{array}{l}\text { Dependent } \\
\text { variable }\end{array}$ & Tax revenue (TR) & TR & Tax revenue (\% of GDP) & $\begin{array}{l}\text { World Bank Database } \\
\text { IMF Database }\end{array}$ \\
\cline { 2 - 5 } & Tax on income (TOI) & TOI & $\begin{array}{l}\text { Tax on income, profit and capital } \\
\text { gains (\% of revenue })\end{array}$ & $\begin{array}{l}\text { World Bank Database } \\
\text { IMF Database }\end{array}$ \\
\cline { 2 - 6 } & Individual income tax & ITI & $\begin{array}{l}\text { Individual Income Tax Revenue } \\
(\% \text { of GDP })\end{array}$ & IMF Fund Database \\
& Corporate income tax & CTI & $\begin{array}{l}\text { Corporate Income Tax Revenue } \\
(\% \text { of GDP })\end{array}$ & IMF Database \\
\hline Independent & $\begin{array}{l}\text { Financial } \\
\text { inclusion }: \text { Bank account }\end{array}$ & & $\begin{array}{l}\text { The percentage of respondent who } \\
\text { are reports having bank account or }\end{array}$ & $\begin{array}{l}\text { Global } \\
\text { inclusion }\end{array}$ \\
\hline
\end{tabular}




\begin{tabular}{|c|c|c|c|c|}
\hline \multirow[t]{2}{*}{ variable } & \multicolumn{2}{|l|}{$(\%$ age $15+)$} & \multirow{2}{*}{$\begin{array}{l}\text { report personally using a mobile } \\
\text { money service in last year. } \\
\text { The percentage of respondents } \\
\text { who report having a credit card }\end{array}$} & \multirow{2}{*}{ 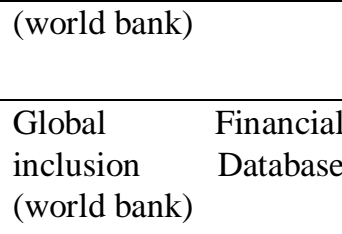 } \\
\hline & $\begin{array}{l}\text { Financial } \\
\text { inclusion :Credit card } \\
\text { ownership (\% age } 15+)\end{array}$ & FIC & & \\
\hline \multirow[t]{8}{*}{$\begin{array}{l}\text { Control } \\
\text { variables }\end{array}$} & Trade openness & Trade & $\begin{array}{l}\text { Trade is the sum of exports and } \\
\text { imports of goods and services (\% } \\
\text { of GDP) }\end{array}$ & $\begin{array}{lr}\text { World Bank } & \text { national } \\
\text { accounts } & \text { data } \\
\text { OECD } & \text { National } \\
\text { Accounts data files. }\end{array}$ \\
\hline & GDP & GDP & $\begin{array}{l}\text { Gross domestic product divided by } \\
\text { midyear population }\end{array}$ & $\begin{array}{lr}\text { World Bank } & \text { national } \\
\text { accounts } & \text { data } \\
\text { OECD } & \text { National } \\
\text { Accounts data files. }\end{array}$ \\
\hline & Political stability & PS & $\begin{array}{l}\text { Political stability and the absence } \\
\text { of violence }\end{array}$ & World Bank Database \\
\hline & Tariff & TRFF & $\begin{array}{l}\text { Simple mean applied tariff rate is } \\
\text { the unweighted average of } \\
\text { effectively applied rates for all } \\
\text { products subject to tariffs ( } \% \text { of all } \\
\text { products) }\end{array}$ & World Bank Database \\
\hline & Government debt & GOVD & $\begin{array}{l}\text { Central government debt which i s } \\
\text { the entire stock of direct } \\
\text { government fixed-term contractual } \\
\text { obligations to others outstanding } \\
\text { on a particular date ( } \% \text { of GDP). }\end{array}$ & $\begin{array}{l}\text { World bank Database } \\
\text { IMF Database }\end{array}$ \\
\hline & Inflation & INF & $\begin{array}{lll}\begin{array}{l}\text { Inflation, } \\
(\text { annual \%) }\end{array} & \text { consumer } & \text { prices } \\
\end{array}$ & IMF Database \\
\hline & Income tax rate & ITR & Income Tax Rate (\%) & $\begin{array}{l}\text { IMF Database, Heritage } \\
\text { Foundation, Index of } \\
\text { economic freedom }\end{array}$ \\
\hline & Corporate tax rate & CTR & Corporate Tax Rate (\%) & IMF Database \\
\hline
\end{tabular}

To the best of our knowledge, this is the first empirical study to test the link between financial inclusion and tax revenues in Europe using the Global Findex database. This research focuses on European countries because prior empirical studies test the association between financial inclusion and tax revenues using international samples (e.g. Maherali, 2007; Oz-Yalaman, 2019). However, financial inclusion can vary from region to region, which may affect the overall association between financial inclusion and tax revenues. Thus, analysing the connection between financial inclusion and tax revenue in a regional context can shed more light on this area. In this study, the sample countries share many characteristics and have few differences in the structure and regulation of their financial system. Relying on specific sub-samples of the World Bank Global Financial inclusion survey can lead to additional insights (Botrić and Broz, 2017).

\subsection{Model}

Following existing financial inclusion literature, the Ordinary Least Square (OLS) estimation technique is applied to investigate the effect of financial inclusion tax revenue (e.g. Sarma and Pais, 2011; Zhang and Posso, 2019; Oz-Yalaman, 2019). This study uses four different dependent variables for tax revenue. Our estimating equations are:

$T R_{i t}=\beta 0+\beta 1 F I_{i t}+\beta 2$ Trade $_{i t}+\beta 3 G D P_{i t}+\beta 4 P S_{i t}+\beta 5 T_{R F F_{i t}}+\beta 6 G O V D_{i t}+\beta 7 I N F_{i t}+\beta 8 I_{\text {ITR }}{ }_{i t+} \beta \operatorname{CTR}_{i t+} \mu_{t}+$ 


$$
\begin{aligned}
& \text { TOI }_{i t}=\beta 0+\beta 1 F I_{i t}+\beta 2 \text { Trade }_{i t}+\beta 3 G D P_{i t}+\beta 4 P S_{i t}+\beta 5 T_{R F F_{i t}}+\beta 6 G O V D_{i t}+\beta 7_{I N F_{i t}}+\beta 8 \text { ITR }_{i t+} \beta 9 \operatorname{CTR}_{i t}+\mu_{t} \\
& +\dot{\varepsilon}_{i, t} \\
& I T I_{i t}=\beta 0+\beta 1 F I_{i t}+\beta 2 \text { Trade }_{i t}+\beta 3 G D P_{i t+} \beta 4 P S_{i t}+\beta 5 \text { TRFF }_{i t}+\beta 6 G O V D_{i t}+\beta \text { INF }_{i t}+\beta 8 \text { ITR }_{i t+} \beta 9_{C T R_{i t}+\mu_{t}} \\
& +\dot{\varepsilon}_{i, t} \\
& C T I_{i t}=\beta 0+\beta I_{F I}+\beta 2 \text { Trade }_{i t}+\beta 3 G D P_{i t}+\beta 4 P S_{i t}+\beta 5 T_{R F F_{i t}}+\beta 6 G O V D_{i t}+\beta 7_{I N F_{i t}}+\beta 8 I T R_{i t+} \beta 9 \operatorname{CTR}_{i t+} \mu_{t} \\
& +\dot{\varepsilon}_{i, t}
\end{aligned}
$$

Where $i$ refers to the country and $t$ to the year, $\beta 0$ constant intercept ; TR is tax revenue (\% of GDP); TOI is taxes on income (\% of revenue); ITI is individual income tax revenue (\% of GDP); CTI and corporate income tax revenue (\% of GDP); FI is financial inclusion; Trade is trade openness; GDP is GDP per capita; $P S$ is political stability; TRFF is tariff rate; GOVD is central government debt; INF is inflation rate; ITR is income tax rate; CTR is corporate tax rate.

In the regressions, the dependent variable is a ratio such as tax revenues/GDP; this research follows prior studies and uses logistic transformation of dependent variables to fit a model (e.g., Oz-Yalaman, 2019). Financial inclusion is initially considered through indicators that calculate the percentage of population using specified financial service.

\subsection{Measures of Financial Inclusion}

In line with prior literature, financial inclusion is investigated using two different measures. The first is the bank account ( $\%$ of age +15 ), which is the percentage of respondents who report having an account at a bank or another type of financial institution or report personally using a mobile money service (Sarma and Pais, 2011; Musau et al, 2018; Zachosova et al., 2018).

Literature suggests that one of the key issues of measuring financial inclusion depending on the percentage of bank account is the problem of inactive users. Ozili (2020) argue that after investing substantial effort and resources to include individuals into the formal financial system, there is a chance that these individuals intend to become inactive users after a period of time. This can happen when the account exists on paper but is not used for a while or when an individual chooses to open formal accounts but refuses to own credit or debit cards (Shankar, 2013; Ozili, 2020). Therefore, a second proxy for financial inclusion is used; this measure focuses on credit card ownership (\% age 15+), which is defined as the percentage of respondents who report having a credit card (Zachosova et al., 2018; Zhang and Posso, 2019).

\subsection{Measures of Tax Revenue}

Previous studies employ various proxies for direct tax revenue (Karran, 1985; Bohn, 1990; Hsieh and Parker, 2007; Taha, Colombage, Maslyuk, and Nanthakumar, 2013; Castro and Camarillo, 2014; Alena, Lucia, and Slavomira, 2017; Oz-Yalaman, 2019). In this research, four measures are used for tax revenues: tax revenue (\% of GDP), taxes on income ( $\%$ of revenue), and individual income tax revenue ( $\%$ of GDP), and corporate income tax revenue (\% of GDP). All the necessary data for the tax revenue (\% of GDP) and taxes on income (\% of revenue) variables have been gathered from World Banks' World Database. The data for individual income tax revenue (\% of GDP), and corporate income tax revenue (\% of GDP) variables are collected using the International Monetary Fund database.

According to existing research, there is an expected positive association between tax revenues and financial inclusion (e.g., Maherali, 2017; Oz-Yalaman, 2019). Financial inclusion is expected to make individuals and businesses healthier as their incomes increase. In addition, previous empirical evidences document a negative association between financial inclusion and poverty, leading to higher income equality (Chibba, 2009; Allen et al., 2016; Mohammed, Mensah, and Gyeke-Dako, 2017).

In theoretical and empirical literature, several variables are identified as determinant factors of tax revenue. To explain the association between financial inclusion and tax revenues, standard control variables are widely used in the literature. Thus, the following explanatory variables are included as control variables: GDP per capita, Openness degree, degree of political stability, inflation, tariff rate, income tax rate, and corporate tax rate (Agbeyegbe, Stotsky, and WoldeMariam, 2006; Gupta, 2007; Oz-Yalaman, 2019).

GDP per capita is consider the most common determinant of tax revenues that capture level of development, and it is expected to affect tax revenue positively (Agbeyegbe et al., 2006; Gupta, 2007; Castro and Camarillo, 2014). Previous tax effort studies have also showed that openness degree may also affect tax revenues. The degree of political stability represents an institutional factor that may influence tax revenues. Increasing the political stability of the country can improve the efficiency of tax policy, which raises tax revenues (Karagöz, 2013). Furthermore, the inflation rate is included as a control variable; introduced by literature as macroeconomic variable that determines tax revenue. Agbeyegbe et al. (2006) and Tanzi (1989) found that the inflation rate is indeed a significant 
determinant of tax revenue. These studies documented a negative association between inflation rate and tax revenue. A higher inflation rate can alter the value income components that depress tax revenue. In addition, to control for the effect of countries' tax policies, tariff rate, income tax rate, and corporate tax rate are also added (Ebrill, Stotsky, and Gropp, 1999; Agbeyegbe et al., 2006; Oz-Yalaman, 2019).

\section{Results and Discussion}

In this section, the descriptive statistics, correlation coefficients of all dependent variables, and the results of the OLS regressions are presented. The results of this study complement the finding of previous research, identifying financial inclusion as a key determinant of tax revenue and showing that more financial inclusion results in higher tax revenue (Maherali, 2007; Oz-Yalaman, 2019). Table 2 details the descriptive statistics for all tax revenue variables and financial inclusion variables. The descriptive statistics for the control variables are presented in Table 3 .

Table 2. Descriptive statistics for tax variables and financial inclusion

\begin{tabular}{llllll}
\hline Variable & Obs & Mean & Std. Dev. & Min & Max \\
\hline TR & 84 & 3.086495 & 0.1880857 & 2.527807 & 3.59732 \\
\hline TOI & 84 & 3.011142 & 0.4578531 & 1.803876 & 3.872233 \\
\hline ITI & 84 & 1.869091 & 0.5292872 & 0.9799968 & 3.27143 \\
\hline CTI & 84 & 0.8750441 & 0.414045 & -0.2119563 & 1.865206 \\
\hline FIB & 84 & 88.98503 & 12.06657 & 44.59163 & 100 \\
\hline FIC & 84 & 35.5456 & 16.67353 & 10.04441 & 72.40598 \\
\hline
\end{tabular}

Table 3. Descriptive statistics for control variables

\begin{tabular}{llllll}
\hline Variable & Obs & Mean & Std. Dev. & Min & Max \\
\hline Trade & 84 & 128.9588 & 71.15662 & 55.14552 & 400.0795 \\
\hline GDP & 84 & 42873.85 & 23609.4 & 7813.807 & 107361.3 \\
\hline PS & 84 & 0.8690476 & 0.3393744 & 0 & 1 \\
\hline TRFF & 84 & 2.875 & 0.3723468 & 2.23 & 3.29 \\
\hline GOVD & 84 & 10.93479 & 11.39607 & -9.586033 & 50.63219 \\
\hline INF & 84 & 1.751933 & 1.524095 & -1.418184 & 5.789253 \\
\hline ITR & 84 & 31.91548 & 3.063642 & 27.7 & 39.8 \\
\hline CTR & 84 & 27.48214 & 0.8982125 & 25.8 & 30.5 \\
\hline
\end{tabular}

In Table 4, the matrix correlation coefficients are listed. The pair-wise correlation matrix test is used to investigate the existence of a perfect linear relationship among the explanatory variables. As the data shows, the coefficients of the explanatory variables are below 0.7 . Multicollinearity only becomes a concern if the correlation coefficient is above 0.70 (Anderson, Sweeney, and Williams, 1990; Baltagi, 2008; Hsiao, 2014).

Table 4. Correlation matrix of the dependent variables

\begin{tabular}{|c|c|c|c|c|c|c|c|c|c|c|}
\hline & FIB & FIC & Trade & GDP & PS & TRFF & GOVD & INF & ITR & CTR \\
\hline FIB & 1 & & & & & & & & & \\
\hline FIC & 0.6361 & 1 & & & & & & & & \\
\hline Trade & 0.1148 & 0.2269 & 1 & & & & & & & \\
\hline GDP & 0.0033 & -0.0051 & -0.1352 & 1 & & & & & & \\
\hline PS & -0.1714 & 0.0704 & -0.0311 & 0.1348 & 1 & & & & & \\
\hline
\end{tabular}




\begin{tabular}{lllllllllll}
\hline TRFF & 0.1448 & 0.002 & 0.0483 & 0.1299 & 0.2741 & 1 & & & & \\
\hline GOVD & 0.0367 & 0.161 & -0.1617 & -0.0141 & 0.332 & 0.1591 & 1 & & & \\
\hline INF & -0.1862 & -0.0181 & -0.0186 & -0.0142 & -0.2297 & -0.679 & -0.1245 & 1 & & \\
\hline ITR & 0.0877 & 0.0659 & -0.0105 & -0.0928 & -0.1151 & 0.0288 & -0.0473 & -0.1585 & 1 & \\
\hline CTR & -0.0665 & 0.0467 & 0.0765 & -0.0988 & -0.0117 & 0.0383 & -0.1299 & -0.0752 & 0.1921 & 1
\end{tabular}

The possible presence of multicollinearity problem is also tested using the variance inflation factor (VIF) test. Following the test, the results confirm that there are no multicollinearity problems with the independent and control variables. None of the VIFs exceed 2. According to prior studies, the value of the VIF should not exceed 10, and all the values reported for the VIF test are below the commonly accepted VIF cut-off threshold of 10 (Field, 2000; Hassan, 2009). Results of VIF test are reported in Appendix Table A1.

In Tables 5 to 8 , the OLS estimation results are listed. Table 5 presents the results of Model 1 , which investigates the effect of financial inclusion as measured by bank account (\% age 15+) and credit card ownership (\% age 15+) on tax revenue as measured by $T R$. The regression results reveal that both financial inclusion proxies have significant and positive effect on $T R$ at the $1 \%$ level. These results suggest that financial inclusion is a channel for tax revenue where higher financial inclusion leads to an increase in tax revenue. Thus, as more individuals become financially included in the formal financial sector, their income and wealth will increase, which in turn raises their tax contributions. These results are consistent and conform to the findings of prior studies (Maherali, 2007; Oz-Yalaman, 2019; Mitchell and Scott, 2019).

Table 5. Regression results of Model 1: dependent variable tax revenue

\begin{tabular}{|c|c|c|c|c|}
\hline & \multicolumn{2}{|c|}{ Bank account (\% age 15+) } & \multicolumn{2}{|c|}{ Credit card ownership (\% age $15+)$} \\
\hline & Coefficient & T-statistics & Coefficient & T-statistics \\
\hline \multirow[t]{2}{*}{ FI } & 0.0065692 & 4.02 & 0.0033152 & 2.72 \\
\hline & $(0.0000) * * *$ & & $(0.008)^{* * *}$ & \\
\hline \multirow[t]{2}{*}{ Trade } & 0.0001913 & 0.72 & 0.0001251 & 0.43 \\
\hline & $(0.4760)$ & & $(0.667)$ & \\
\hline \multirow[t]{2}{*}{ GDP } & 0.0001240 & 1.4 & 0.0001160 & 1.24 \\
\hline & $(0.051) *$ & & $(0.062)^{*}$ & \\
\hline \multirow[t]{2}{*}{ PS } & 0.0872227 & 1.4 & 0.0184924 & 0.29 \\
\hline & $(0.1640)$ & & $(0.77)$ & \\
\hline \multirow[t]{2}{*}{ TRFF } & -0.6175735 & -2.39 & -0.623734 & -2.29 \\
\hline & $(0.0190)^{* *}$ & & $(0.025)^{* *}$ & \\
\hline \multirow[t]{2}{*}{ GOVD } & -0.0021048 & -1.17 & -0.0025196 & -1.31 \\
\hline & $(0.2470)$ & & $(0.195)$ & \\
\hline \multirow[t]{2}{*}{ INF } & 0.0189024 & 0.81 & 0.0031542 & 0.13 \\
\hline & $(0.4210)$ & & $(0.896)$ & \\
\hline \multirow[t]{2}{*}{ ITR } & 0.0037833 & 0.6 & 0.0042225 & 0.64 \\
\hline & $(0.5500)$ & & $(0.527)$ & \\
\hline \multirow[t]{2}{*}{ CTR } & 0.0105861 & 0.5 & 0.000104 & 0.3 \\
\hline & $(0.6170)$ & & $(0.996)$ & \\
\hline \multirow[t]{2}{*}{ dum2011 } & -0.5243967 & -2.44 & -0.5489064 & -2.43 \\
\hline & $(0.0170)^{* *}$ & & $(0.018)^{* *}$ & \\
\hline
\end{tabular}




\begin{tabular}{|c|c|c|c|c|}
\hline dum2014 & 0.0016891 & 0.03 & -0.029657 & -0.49 \\
\hline & $(0.9770)$ & & $(0.628)$ & \\
\hline \multirow[t]{2}{*}{ Cons } & 3.982687 & 4.12 & 4.856564 & 4.85 \\
\hline & $(0.0000)^{* * *}$ & & $(0.0000)^{* * *}$ & \\
\hline $\mathbf{R 2}$ & 0.3273 & & 0.2527 & \\
\hline Prob(F-statistics) & 0.0015 & & 0.0226 & \\
\hline
\end{tabular}

P-values are reported in parentheses, $* * *, * *$, and $*$ indicate statistical significance at the $1 \%, 5 \%$ and $10 \%$ levels respectively.

In Tables 6 and 7, the regression results for Models 2 and 3 are presented, respectively. These models investigate the effect of financial inclusion variables on tax revenue. In Table 6 , the dependent variable is tax revenue, which is measured using taxes on income, profits and capital gains as percentage of total revenues. While in Table 7, tax revenue is measured by individual income tax revenue in percent of GDP.

These analyses demonstrate that the impact of financial inclusion on these measures of tax revenue is positive and statistically strong. These results indicate that as financial inclusion increases, the government will receive more tax revenues. These results reported in Table 6 and Table 7 are consistent using different proxies for financial inclusion and when tax revenue is measured as tax on income as a percentage of revenue or when measured as individual income tax revenue as a percentage of GDP. Thus, the results reported in Tables 6 and 7 maintain the significance and sign of the results in Table 5 regarding the impact of financial inclusion in tax revenue.

Table 6. Regression results of Model 2: dependent variable tax on income

\begin{tabular}{|c|c|c|c|c|}
\hline & \multicolumn{2}{|c|}{ Bank account (\% age 15+) } & \multicolumn{2}{|c|}{ Credit card ownership (\% age $15+$ ) } \\
\hline & Coefficient & T-statistics & Coefficient & T-statistics \\
\hline \multirow[t]{2}{*}{ FI } & 0.0117237 & 2.89 & 0.0104331 & 3.76 \\
\hline & $(0.0050)^{* * *}$ & & $(0.0000)^{* * *}$ & \\
\hline \multirow[t]{2}{*}{ Trade } & 0.00110 & 1.66 & 0.0007007 & 1.07 \\
\hline & $(0.1020)$ & & $(0.29)$ & \\
\hline \multirow[t]{2}{*}{$\overline{\text { GDP }}$} & 0.0000027 & 1.23 & 0.00026800 & 1.26 \\
\hline & $(0.0210) * *$ & & $(0.024) * *$ & \\
\hline \multirow[t]{2}{*}{ PS } & 0.0518708 & 0.34 & -0.0746947 & -0.52 \\
\hline & $(0.7370)$ & & $(0.605)$ & \\
\hline \multirow[t]{2}{*}{ TRFF } & -0.0480697 & -0.08 & -0.0871965 & -0.14 \\
\hline & $(0.9400)$ & & $(0.888)$ & \\
\hline \multirow[t]{2}{*}{ GOVD } & 0.0145739 & 3.26 & 0.01254 & 2.86 \\
\hline & $(0.0020)^{* * *}$ & & $(0.006) * * *$ & \\
\hline \multirow[t]{2}{*}{ INF } & 0.0446748 & 0.77 & 0.0225901 & 0.41 \\
\hline & $(0.4430)$ & & $(0.681)$ & \\
\hline \multirow[t]{2}{*}{ ITR } & 0.0193097 & 1.23 & 0.0180284 & 1.19 \\
\hline & $(0.2210)$ & & $(0.237)$ & \\
\hline \multirow[t]{2}{*}{ CTR } & 0.0693963 & 1.33 & 0.0468844 & 0.93 \\
\hline & $(0.1890)$ & & $(0.355)$ & \\
\hline dum2011 & -0.0547405 & -0.1 & -0.1362952 & -0.26 \\
\hline
\end{tabular}




\begin{tabular}{|c|c|c|c|c|}
\hline & $(0.9180)$ & & $(0.792)$ & \\
\hline \multirow[t]{2}{*}{ dum2014 } & 0.0378717 & 0.26 & -0.0017769 & -0.01 \\
\hline & $(0.7950)$ & & $(0.99)$ & \\
\hline \multirow[t]{2}{*}{ Cons } & -0.7192239 & -0.3 & 0.9859884 & 0.43 \\
\hline & $(0.7660)$ & & $(0.666)$ & \\
\hline $\mathbf{R 2}$ & 0.3002 & & 0.3471 & \\
\hline Prob(F-statistics) & 0.0042 & & 0.0006 & \\
\hline \multicolumn{5}{|c|}{$\begin{array}{l}\text { P-values are reported in parentheses, } * * *, * * \text {, and } * \text { indicate statistical significance at the } 1 \%, 5 \% \text { and } \\
10 \% \text { levels respectively. }\end{array}$} \\
\hline
\end{tabular}

Table 7. Regression results of Model 3: dependent variable individual income tax revenue

\begin{tabular}{|c|c|c|c|c|}
\hline & \multicolumn{2}{|c|}{ Bank account (\% age 15+) } & \multicolumn{2}{|c|}{ Credit card ownership (\% age $15+$ ) } \\
\hline & Coefficient & T-statistics & Coefficient & T-statistics \\
\hline \multirow[t]{2}{*}{ FI } & 0.0330044 & 8.45 & 0.0239601 & 8.87 \\
\hline & $(0.0000) * * *$ & & $(0.0000) * * *$ & \\
\hline \multirow[t]{2}{*}{ Trade } & 0.00155 & 2.42 & 0.00233 & 3.64 \\
\hline & $(0.0180)^{* *}$ & & $(0.001)^{* * *}$ & \\
\hline \multirow[t]{2}{*}{ GDP } & 0.000261 & 1.23 & 0.00237 & 1.14 \\
\hline & $(0.022)^{* *}$ & & $(0.025)^{* *}$ & \\
\hline \multirow[t]{2}{*}{ PS } & 0.2353386 & 1.58 & -0.1162873 & -0.83 \\
\hline & $(0.1170)$ & & $(0.408)$ & \\
\hline \multirow[t]{2}{*}{ TRFF } & 0.282127 & 0.46 & 0.2056807 & 0.34 \\
\hline & $(0.6490)$ & & $(0.734)$ & \\
\hline \multirow[t]{2}{*}{ GOVD } & 0.004957 & 1.15 & 0.0091332 & 2.14 \\
\hline & $(0.2540)$ & & $(0.036)^{* *}$ & \\
\hline \multirow[t]{2}{*}{ INF } & 0.0809694 & 1.45 & 0.0115847 & 0.22 \\
\hline & $(0.1510)$ & & $(0.829)$ & \\
\hline \multirow[t]{2}{*}{ ITR } & 0.0001839 & 0.01 & -0.0009492 & -0.06 \\
\hline & $(0.9900)$ & & $(0.949)$ & \\
\hline \multirow[t]{2}{*}{ CTR } & 0.0658181 & 1.31 & 0.0070014 & 0.14 \\
\hline & $(0.1960)$ & & $(0.887)$ & \\
\hline \multirow[t]{2}{*}{ dum2011 } & 0.1862721 & 0.36 & 0.0019812 & 0.11 \\
\hline & $(0.7180)$ & & $(0.997)$ & \\
\hline \multirow[t]{2}{*}{ dum2014 } & 0.1542393 & 1.1 & 0.0231019 & 0.17 \\
\hline & $(0.2750)$ & & $(0.864)$ & \\
\hline \multirow[t]{2}{*}{ Cons } & -3.787834 & -1.64 & 0.8381663 & 0.38 \\
\hline & $(0.1060)$ & & $(0.706)$ & \\
\hline $\mathbf{R 2}$ & 0.5139 & & 0.5376 & \\
\hline Prob(F-statistics) & 0.0000 & & 0.0000 & \\
\hline
\end{tabular}


Some of the results obtained for Model 4 are slightly different to those for Model 1 to Model 3. The results reported in Table 8 still exhibit positive and significant correlation between financial inclusion and tax revenue when corporate income tax revenue is used as a proxy for tax revenue. However, when using bank account (\% age 15+) as a measure for financial inclusion, the results have a weak positive association with tax revenue (at $10 \%$ level of significant). Nevertheless, the second measure for financial inclusion (credit card ownership \% age 15+) is still showing highly significant positive correlation with corporate income tax revenue at $1 \%$ level.

Table 8. Regression results of Model 4: dependent variable corporate income tax revenue

\begin{tabular}{|c|c|c|c|c|}
\hline & \multicolumn{2}{|c|}{ Bank account (\% age 15+) } & \multicolumn{2}{|c|}{ Credit card ownership (\% age $15+)$} \\
\hline & Coefficient & T-statistics & Coefficient & T-statistics \\
\hline \multirow[t]{2}{*}{ FI } & 0.0062484 & 1.85 & 0.0067382 & 2.91 \\
\hline & $(0.0680)^{*}$ & & $(0.0050)^{* * *}$ & \\
\hline \multirow[t]{2}{*}{ Trade } & 0.0026526 & 4.81 & 0.0023681 & 4.32 \\
\hline & $(0.0000)^{* * *}$ & & $(0.0000)^{* * *}$ & \\
\hline \multirow[t]{2}{*}{ GDP } & 0.000137000 & 0.070 & 0.000000130 & 0.07 \\
\hline & $(0.941)$ & & $(0.9420)$ & \\
\hline \multirow[t]{2}{*}{ PS } & 0.3313648 & 2.58 & 0.2628906 & 2.19 \\
\hline & $(0.0120)^{* * *}$ & & $(0.0310)^{* *}$ & \\
\hline \multirow[t]{2}{*}{ TRFF } & -0.4242336 & -0.8 & -0.4524219 & -0.88 \\
\hline & $(0.4290)$ & & $(0.3840)$ & \\
\hline \multirow[t]{2}{*}{ GOVD } & 0.0085184 & 2.29 & 0.0070971 & 1.94 \\
\hline & $(0.0250)^{* *}$ & & $(0.0560)^{*}$ & \\
\hline \multirow[t]{2}{*}{ INF } & 0.0559219 & 1.16 & 0.0661228 & 1.45 \\
\hline & $(0.2500)$ & & $(0.1520)$ & \\
\hline \multirow[t]{2}{*}{ ITR } & 0.0119659 & 0.92 & 0.0107445 & 0.85 \\
\hline & $(0.3610)$ & & (0.3970) & \\
\hline \multirow[t]{2}{*}{ CTR } & 0.0048195 & 0.11 & -0.0081707 & -0.19 \\
\hline & $(0.9120)$ & & $(0.8460)$ & \\
\hline \multirow[t]{2}{*}{ dum2011 } & -0.2309534 & -0.52 & -0.2842788 & -0.66 \\
\hline & $(0.6040)$ & & $(0.5100)$ & \\
\hline \multirow[t]{2}{*}{ dum2014 } & -0.1736573 & -1.43 & -0.1905408 & -1.65 \\
\hline & $(0.1560)$ & & $(0.1040)$ & \\
\hline \multirow[t]{2}{*}{ Cons } & 0.5281408 & 0.26 & 1.474944 & 0.78 \\
\hline & $(0.7920)$ & & $(0.4400)$ & \\
\hline $\mathbf{R 2}$ & 0.4075 & & 0.4446 & \\
\hline Prob(F-statistics) & 0.0000 & & 0.0000 & \\
\hline
\end{tabular}

Overall, all regressions models confirm that financial inclusion has significant positive association with tax revenue collection in European countries. This positive impact is consistent when using different proxies of tax revenues and financial inclusion. 
Regarding the control variables, the obtained results confirmed the findings of prior theoretical and empirical research; namely, the positive impact of GDP per capita and trade openness (Agbeyegbe et al., 2006; Arif and Rawat, 2018; Gupta, 2007). GDP per capita, which captures the level of development, is found to be positively associated with tax revenues. This shows that European countries, as developed economies tend to have more efficient tax administration; this can explain the positive association between GDP per capita and tax revenue proxies (Pessino and Fenochietto, 2010).

The positive association between trade openness and tax revenue is significant when using individual tax revenue and corporate tax revenue to measure tax, as reported in Tables 7 and 8. This is consistent with the finding of Agbeyegbe et al. (2006) who found that trade openness is not strongly linked to the total tax revenue, but has positive effect on income tax revenue. Moreover, a higher level of trade openness can lead to more profit and hence generate higher tax revenues. Thus, greater trade openness is associated with an increase in individual and corporate income tax revenues.

Government debt also has a positive and significant association with taxes on income, individual income tax revenue, and corporate income tax revenue. In this case, a higher level of government debt can influence tax revenue positively because this debt needs to be financed (Chaudhry and Munir, 2010; Oz-Yalaman, 2019). Furthermore, inflation, which is used as a proxy for macroeconomic stability, is found to be positive but insignificant with the tax revenue of the European countries. Prior tax empirical literature documents positive and insignificant relationship between tax and inflation (e.g., Arif and Rawat, 2018). For instance, Shin (1969) shows that for 16 high income countries inflation and other control variables were not significant with tax ratio. Other studies have documented a negative relationship between tax revenue and inflation (Pessino and Fenochietto, 2010). Nevertheless, Arin and Koray (2006) provide empirical evidence that different taxes will have different effects, which is a key factor behind the variation in the mixed signs for macroeconomic variables in the literature.

As an institutional variable, political stability is positively correlated with corporate income tax revenue in Table 8 . Thus, by achieving a higher level of political stability, the government can generate more tax revenue (Chaudhry and Munir, 2010). In the study by Gupta (2007), political stability is noted to be an effective factor in tax revenue, but only across certain specifications of the analysis. Similarly, Arif and Rawat (2018) indicate that political stability is a variable included in governance indicators leading to efficient tax administration that consequently increases the performance of the tax revenues. In other words, people can have better perception of their governments, making them more compliant with tax regulation and less likely to engage in tax evasion (Castro and Camarillo, 2014).

Policy variables such as corporate tax rate, income tax rate, and tariff rate are insignificant in most specifications. These results are consistent with prior studies that document insignificant and inconsistent signs in some regressions for the relation between tax revenues and policy variables (e.g., Oz-Yalaman, 2019). This study shows that financial inclusion has the potential to improve the government's tax revenue, especially when a large share of the population is included in the formal financial system. Furthermore, the results presented in this paper indicate that financial inclusion can improve individual and business income.

\subsection{Additional Analyses}

Several proxies are used for tax revenue and for financial inclusion to check the robustness of the results. Furthermore, in this section, the association between financial inclusion and tax revenue is tested by using random effect model.

Table 9. Regression results of Model 1-4: dependent variable tax revenue

\begin{tabular}{|c|c|c|c|c|c|c|c|c|}
\hline & \multicolumn{2}{|l|}{ Model 1} & \multicolumn{2}{|l|}{ Model 2} & \multicolumn{2}{|l|}{ Model 3} & \multicolumn{2}{|l|}{ Model 4} \\
\hline & FIB & FIC & FIB & FIC & FIB & FIC & FIB & FIC \\
\hline \multirow[t]{2}{*}{ FI } & $0.00323^{* *}$ & 0.00602 & $0.00435^{*}$ & $0.00407^{*}$ & $0.00700^{* *}$ & $0.00778 * * *$ & -0.00600 & $0.00574^{*}$ \\
\hline & $(0.0470)$ & $(0.6430)$ & $(0.0810)$ & $(0.0520)$ & $(0.0110)$ & $(0.0000)$ & $(0.8840)$ & $(0.0650)$ \\
\hline \multirow[t]{2}{*}{ Trade } & 0.00023 & 0.00028 & 0.00041 & 0.00033 & -0.00058 & -0.00042 & $0.00172^{* *}$ & $0.00153^{*}$ \\
\hline & $(0.5430)$ & $(0.4890)$ & $(0.5640)$ & $(0.6360)$ & $(0.4490)$ & $(0.5650)$ & $(0.0460)$ & $(0.0670)$ \\
\hline GDP & $-0.00709 *$ & $-0.00645^{*}$ & -0.00561 & -0.00420 & -0.00362 & -0.00192 & $-0.00189^{*}$ & $-0.00184 *$ \\
\hline
\end{tabular}




\begin{tabular}{|c|c|c|c|c|c|c|c|c|}
\hline & $(0.0570)$ & $(0.0860)$ & $(0.2970)$ & $(0.4210)$ & $(0.5270)$ & $(0.7230)$ & $(0.0700)$ & $(0.0760)$ \\
\hline \multirow[t]{2}{*}{ PS } & 0.03474 & 0.03087 & 0.09657 & $0.10292^{* * *}$ & $0.07626^{*}$ & $0.08707 * *$ & $0.18374 * *$ & 0.19794 *** \\
\hline & $(0.1950)$ & $(0.2550)$ & $(0.0130)$ & $(0.0070)$ & $(0.0630)$ & $(0.0260)$ & $(0.0150)$ & $(0.0080)$ \\
\hline \multirow[t]{2}{*}{ TRFF } & $-0.69003 *$ & -0.70558 & 0.06233 & 0.01833 & 0.08355 & -0.00084 & -0.00500 & -0.05650 \\
\hline & $(0.0960)$ & $(0.1090)$ & $(0.1200)$ & $(0.9850)$ & $(0.9370)$ & $(0.9990)$ & $(0.9950)$ & $(0.9440)$ \\
\hline \multirow[t]{2}{*}{ GOVD } & -0.00055 & -0.00052 & -0.00184 & $-0.00336^{*}$ & $-0.00355^{*}$ & $-0.00598 * * *$ & 0.00204 & 0.00012 \\
\hline & $(0.6530)$ & $(0.6980)$ & $(0.3130)$ & $(0.0830)$ & $(0.0670)$ & $(0.0030)$ & $(0.5350)$ & $(0.9720)$ \\
\hline \multirow[t]{2}{*}{ INF } & 0.01140 & 0.00717 & $0.01531 *$ & -0.00875 & 0.01003 & -0.00204 & -0.01971 & -0.02207 \\
\hline & $(0.2010)$ & $(0.4150)$ & $(0.0870)$ & $(0.4730)$ & $(0.4630)$ & $(0.8720)$ & $(0.4320)$ & $(0.3650)$ \\
\hline \multirow[t]{2}{*}{ ITR } & -0.00007 & 0.00020 & 0.00247 & 0.00287 & 0.00173 & 0.00099 & 0.00227 & 0.00076 \\
\hline & $(0.9730)$ & $(0.9270)$ & $(0.4100)$ & $(0.3310)$ & $(0.5900)$ & $(0.7470)$ & $(0.7050)$ & $(0.8990)$ \\
\hline \multirow[t]{2}{*}{ CTR } & 0.00718 & 0.00444 & 0.00411 & 0.00085 & 0.01768 & 0.01058 & $-0.04324 * *$ & $-0.04380 * *$ \\
\hline & $(0.3390)$ & $(0.5520)$ & $(0.7040)$ & $(0.9340)$ & $(0.1210)$ & $(0.3190)$ & $(0.0430)$ & $(0.0360)$ \\
\hline \multirow[t]{2}{*}{ dum2011 } & $-0.58523^{*}$ & $-0.60515^{*}$ & $-0.05930 * * *$ & -0.03008 & 0.01108 & -0.07005 & -0.05555 & -0.09332 \\
\hline & $(0.0740)$ & $(0.0810)$ & $(0.0040)$ & $(0.9680)$ & $(0.9890)$ & $(0.9320)$ & $(0.9340)$ & $(0.8840)$ \\
\hline \multirow[t]{2}{*}{ dum2014 } & -0.00947 & -0.01970 & $-0.05033 * * *$ & -0.06351 & 0.00320 & -0.01577 & $-0.11700^{*}$ & $-0.11297^{*}$ \\
\hline & $(0.7360)$ & $(0.4920)$ & $(0.0050)$ & $(0.2430)$ & $(0.9580)$ & $(0.7870)$ & $(0.0880)$ & $(0.0850)$ \\
\hline \multirow[t]{2}{*}{ Cons } & $4.74209 * * *$ & $5.13126^{* * * *}$ & $2.13352 * * *$ & 0.38100 & 0.50540 & 1.35694 & 1.82827 & 1.82902 \\
\hline & $(0.0000)$ & $(0.0000)$ & $(0.0000)$ & $(2.6681)$ & $(0.8810)$ & $(0.6800)$ & $(0.5100)$ & $(0.4820)$ \\
\hline
\end{tabular}

The dependent variable is measured as Tax revenue in model 1, Taxes on income in model 2, Individual Income Tax Revenue in model 3, and Corporate Income Tax Revenue in model 4. P-values are reported in brackets, ***, **, and * indicate statistical significance at $1 \%, 5 \%$ and $10 \%$ levels respectively.

To choose between the fixed effect model and the random effect model, the Hausman (1978) test is applied. The results from the Hausman test indicate the random effect model would be more appropriate.

In Table 9, the results of the random effect model are presented. In this, two variables are used to measure financial inclusion: bank account and credit card ownership. The results are consistent with the results in the previous section in sign, magnitude, and significance. In general, both measures of financial inclusion are still positively and statistically significant to tax revenue in European countries.

To extend this research further, it can be extended by considering separate measures for direct and indirect tax revenues. Moreover, this paper has focused on the regional level by using a sample from European countries; future researches may use different regional classification to examine the effect of financial inclusion on taxation; for example, Latin America and Caribbean, East Asia and the Pacific, Middle Sub-Saharan Africa, East and North Africa, and South Asia. In doing so, this enables comparability between analysed regions in term of the impact of financial inclusion on tax revenue and provides a deeper insight of the issue.

\section{Conclusions}

The role of financial inclusion in enhancing economic development and in alleviating poverty level has become a topic of interest among academics and policymakers. Over the last decade, financial inclusion has evolved to be a key policy tool for governments to achieve economic stability. Thus, given the increased attention financial inclusion has received in the last few years, this paper investigate the impact of financial inclusion on tax revenue in a sample of European countries over the 2011 - 2017 period.

Few previous studies have tested the association between financial inclusion and tax revenue. However, these studies rely on international samples, while this paper represents the first attempt to discuss this topic in the context of 
European nations. Additionally, this study further expands prior financial inclusion literature by using different proxies for financial inclusion and tax revenues.

The research results confirm the significant positive impact of financial inclusion on four different tax revenue measures: tax revenue (\% of GDP), tax on income (\% of revenue), and individual income tax revenue (\% of GDP), and corporate income tax revenue (\% of GDP). This positive association is consistent using two proxies for financial inclusion: bank account (\% age 15+) and credit card ownership (\% age 15+). Hence, the study observed that when more people are financially included in the formal financial system, their tax contribution to the government will increase. Thus, the results indicate that financial inclusion can be considered as a determinant of tax revenue, and therefore, regulators and policymakers can take advantage of the benefits behind financial inclusion. This can be achieved by investing more attention in this subject and by prioritising financial inclusion in their policy design. Moreover, future researches can shed more lights on the impact of financial inclusion on tax revenue by using different regional classification.

\section{References}

Agbeyegbe, T. D., Stotsky, J., \& Wolde Mariam, A. (2006). Trade liberalization, exchange rate changes, and tax revenue in sub-Saharan Africa. Journal of Asian Economics, 17(2), 261-284. https://doi.org/10.1016/j.asieco.2005.09.003

Ahamed, M. M., \& Mallick, S. K. (2019). Is financial inclusion good for bank stability? International evidence. Journal of Economic Behavior \& Organization, 157, 403-427. https://doi.org/10.1016/j.jebo.2017.07.027

Alena, A., Lucia, M., \& Slavomíra, M. (2017). Meta-analysis categorization of EU countries in the context of corporate income tax. Contaduría y Administración, 62(3), 1001-1018. https://doi.org/10.1016/j.cya.2017.04.002

Allen, F., Demirguc-Kunt, A., Klapper, L. F., \& Martinez Peria, M. S. (2016). The foundations of financial inclusion: Understanding ownership and use of formal accounts. Journal of Financial Intermediation, 27, 1-30. https://doi.org/10.1596/1813-9450-6290

Anderson, D. R., Sweeney, D. J., \& Williams, T. A. (1990). Statistics for Business and Economics. South Western College, Cincinnati, OH.

Arif, I., \& Rawat, A. S. (2018). Corruption, governance, and tax revenue: evidence from EAGLE countries. Journal of Transnational Management, 23(2-3), 119-133. https://doi.org/10.1080/15475778.2018.1469912

Arin, K. P., \& Koray, F. (2006). Are some taxes different than others? An empirical investigation of the effects of tax policy in Canada. Empirical Economics, 31, 183-193. https://doi.org/10.1007/s00181-005-0032-7

Asuming, P. O., Osei-Agyei, L. G., \& Mohammed, J. I. (2018). Financial inclusion in Sub-Saharan Africa: Recent Trends and Determinants. Journal of African Business, 20(1), 112-134. https://doi.org/10.1080/15228916.2018.1484209

Baltagi, B. (2008). Econometric Analysis of Panel Data (4th ed.). John Wiley \& Sons, NJ.

Bohn, H. (1990). Tax smoothing with financial instruments. The American Economic Review, 80, 1217-1230. https://doi.org/10.2307/2006771

Botrić, V., \& Broz, T. (2017). Gender Differences in Financial Inclusion: Central and South Eastern Europe. South-Eastern Europe Journal of Economics, 15(2), 209-227. Retrieved from https://ojs.lib.uom.gr/index.php/seeje/article/view/9557/9600

Bruhn, M., \& Love, I. (2014). The real impact of improved access to finance: Evidence from Mexico. The Journal of Finance, 69(3), 1347-1376. https://doi.org/10.1111/jofi.12091

Castro, G. Á., \& Camarillo, D. B. R. (2014). Determinants of tax revenue in OECD countries over the period 2001-2011. Contaduría y Administración, 59(3), 35-59. https://doi.org/10.1016/S0186-1042(14)71265-3

Chaudhry, I. S., \& Munir, F. (2010). Determinants of low tax revenue in Pakistan. Pakistan Journal of Social Sciences, 30(2), 439-452.

Chibba, M. (2009). Financial inclusion, poverty reduction and the millennium development goals. The European Journal of Development Research, 21(2) 213-230. https://doi.org/10.1057/ejdr.2008.17

Cull, R., Demirguc-Kunt, A., \& Lyman, T. (2012). Financial inclusion and stability: what does research show?. Working paper No 9443, The World Bank, Washington DC. 
Demirguc-Kunt, A., Klapper, L., \& Singer, D. (2017). Financial inclusion and inclusive growth: A review of recent empirical evidence. Working paper No 8040, Policy Research, 1-25. Washington, DC.

Ebrill, L., Stotsky, J., \& Gropp, R. (1999). Revenue Implications of Trade Liberalization. IMF Occasional Paper 99/80, International Monetary Fund, Washington DC.

Field, A. (2000). Discovering statistics: Using SPSS for windows (1st ed). London, UK, sage.

Gupta, A. S. (2007). Determinants of tax revenue efforts in developing countries. Working paper No. 7-184. International Monetary Fund 1-39.

Hajilee, M., Stringer, D. Y., \& Metghalcji, M. (2017). Financial market inclusion, shadow economy and economic growth: new evidence from emerging economies. The Quarterly Review of Economics and Finance, 66, 149-158. https://doi.org/10.1016/j.qref.2017.07.015

Hassan, M. K. (2009). UAE corporations-specific characteristics and level of risk disclosure. Managerial Auditing Journal, 24(7), 668-687. https://doi.org/10.1108/02686900910975378

Hsiao, C. (2014). Analysis of Panel Data (3rd ed.). Cambridge University Press, Cambridge, MA.

Hsieh, C. T., \& Parker, J. A. (2007). Taxes and growth in a financially underdeveloped country: Evidence from the Chilean investment boom. Economia, 8, 1-40. https://doi.org/10.3386/w12104

Iqbal, B. A., \& Sami, S. (2017). Role of banks in financial inclusion in India. Contaduría y Administración, 62(2), 644-656. https://doi.org/10.1016/j.cya.2017.01.007

Karagöz, K. (2013). Determinants of Tax Revenue: Does sectorial Composition Matter?. Journal of Finance, Accounting and Management, 4(2), 50-63.

Karran, T. (1985). The determinants of taxation in Britain: An empirical test. Journal of Public Policy, 5, 365-386. https://doi.org/10.1017/S0143814X00003160

Kim, D. W., Yu, J. S., \& Hassan, M. K. (2018). Financial inclusion and economic growth in OIC countries. Research in International Business and Finance, 43, 1-14. https://doi.org/10.1016/j.ribaf.2017.07.178

Kim, J. H. (2016). A study on the effect of financial inclusion on the relationship between income inequality and economic growth. Emerging Markets Finance and Trade, 52(2), 498-512. https://doi.org/10.1080/1540496X.2016.1110467

Li., L. (2018). Financial inclusion and poverty: The role of relative income. China Economic Review, 52, 165-191. https://doi.org/10.1016/j.chieco.2018.07.006

Maherali, A. (2017). Financial Inclusion, Digital Payments and Their Impact on Income and Tax Revenue around the World. Master's Thesis, Harvard Extension School.

Mitchell, K., \& Scott, R. H. (2019). Pesos or Plastic? Financial Inclusion and Value-Added Taxes in Argentina, Brazil and Chile. Palgrave Pivot, Springer, Switzerland. https://doi.org/10.1007/978-3-030-14876-8_3

Mohammed, J. I., Mensah, L., \& Gyeke-Dako, A. (2017). Financial inclusion and poverty reduction in Sub-Saharan Africa. African Finance Journal, 19(1), 1-22. https://hdl.handle.net/10520/EJC-74aea6652

Mohan, R. (2006). Economic Growth, Financial Deepening and Financial Inclusion. Working paper, Reserve Bank of India Bulletin, 1305-1320.

Morgan, P., \& Pontines, V. (2014). Financial Stability and Financial Inclusion. Working Paper Series No. 488, Asian Development Bank Institute, Tokyo.

Musau, S., Muathe, S., \& Mwangi, L. (2018). Financial inclusion, bank competitiveness and credit risk of commercial banks in Kenya. International Journal of Financial Research, 9(1), 203-218. https://doi.org/10.5430/ijfr.v9n1p 203

Neaime, S., \& Gaysset, I. (2018). Financial inclusion and stability in MENA: Evidence from poverty and inequality. Finance Research Letters, 24, 230-237. https://doi.org/10.1016/j.frl.2017.09.007

Nnyanzi, J. B., Bbale, J. M., \& Sendi, R. (2018). Financial development and tax revenue: how catalytic are political development and corruption?. International Journal of Economics and Finance, 10(8), 92-104. https://doi.org/10.5539/ijef.v10n8p92

Okoye, L. U., Erin, O., \& Modebe, N. J. (2017). Financial inclusion as a strategy for enhanced economic growth and development. The Journal of Internet Banking and Commerce, 6(2), 1-14. 
Ozili, P. K. (2020). Financial inclusion research around the world: A review. Working Paper, presented at the Forum for Social Economics. https://doi.org/10.1080/07360932.2020.1715238

Oz-Yalaman, G. (2019). Financial inclusion and tax revenue. Central Bank Review, 19(3), 107-113. https://doi.org/10.1016/j.cbrev.2019.08.004

Park, C., \& Mercado, R. (2015). Financial Inclusion, Poverty, and Income Inequality in Developing Asia. Working paper Series No. 426, Asian Development Bank, Manila. https://doi.org/10.2139/ssrn.2558936

Pessino, C., \& Fenochietto, R. (2010). Determining countries' tax effort. Hacienda Pública Española/Revista de Economía Pública, 195(4), 65-87.

Sarma, M., \& Pais, J. (2011). Financial inclusion and development. Journal of International Development, 23, 613-628. https://doi.org/10.1002/jid.1698

Shankar, S. (2013). Financial Inclusion in India: Do microfinance institutions address access barriers?. ACRN Journal of Entrepreneurship Perspectives, 2(1), 60-74. Retrieved from http://www.acrn.eu/resources/Journals/201302d.pdf

Sharma, D. (2016). Nexus between financial inclusion and economic growth Evidence from the emerging Indian economy. Journal of Financial Economic Policy, 8(1), 13-36. https://doi.org/10.1108/JFEP-01-2015-0004

Shin, K. (1969). International Differences in Tax Revenue. Review of Economics and Statistics, 51(2), 213-230. https://doi.org/10.2307/1926733

Taha, R., Colombage, S. R. N., Maslyuk, S., \& Nanthakumar, L. (2013). Does financial system activity affect tax revenue in Malaysia? Bounds testing and causality approach. Journal of Asian Economics, 24, 147-157. https://doi.org/10.1016/j.asieco.2012.11.001

Tanzi, V. (1989). The impact of macroeconomic policies on the level of taxation and the fiscal balance in developing countries. IMF Staff Papers, 36(3), 633-656.

World Bank. (2008). Finance for all? Policies and pitfalls in expanding access. Working paper, Policy Research Report, 2007033387, World Bank, Washington DC.

World Bank. (2010). Financial Access 2010: The State of Financial Inclusion Through the Crisis. Working paper, Consultative Group to Assist the Poor and the World Bank Group, Washington, DC.

World Bank. (2017). Financial Inclusion [Web page]. Retrieved from http://www.worldbank.org/en/topic/financialinclusion/overview

Xu, X. (2019). Trust and Financial Inclusion: A Cross-country Study. Finance Research Letters, 35, 101310. https://doi.org/10.1016/j.frl.2019.101310

Yawe, B., \& Prabhu, J. (2015). Innovation and financial inclusion: A review of the literature. Journal of Payments Strategy \& Systems, 9(3), 215-228.

Zachosova, N., Babina, N., \& Zanora, V. (2018). Research and methodological framework for managing the economic security of financial intermediaries in Ukraine. Banks and Bank systems, 13(4), 119-130. https://doi.org/10.21511/bbs.13(4).2018.11

Zhang, Q., \& Posso, A. (2019). Thinking inside the Box: A Closer Look at Financial Inclusion and Household Income. The Journal of Development Studies, 55(7), 1616-1631. https://doi.org/10.1080/00220388.2017.1380798

\section{Notes}

Note 1. This is the situation when poor people financing behavior is driven by jealousy to emulate the consumption style of richer household (Guven and Sorenson, 2012).

Note 2. The Global Findex dataset represent "the world's most comprehensive dataset on how adults save, borrow, make payments and manage risk" (The World Bank, 2018, https://globalfindex.worldbank.org). 


\section{Appendix}

\begin{tabular}{lll}
\hline Table: A1 & & \\
\hline Results of multicollinearity test & & 1/VIF \\
\hline Variable & VIF & \\
\hline & 1.13 & 0.88174 \\
\hline FI & 1.08 & 0.92519 \\
\hline Trade & 1.09 & 0.91914 \\
\hline GDP & 1.32 & 0.76033 \\
\hline PS & 1.99 & 0.50321 \\
\hline TRFF & 1.21 & 0.82801 \\
\hline GOVD & 2 & 0.50039 \\
\hline INF & 1.1 & 0.9071 \\
\hline ITR & 1.08 & 0.92459 \\
\hline CTR & & \\
\hline & 1.33 & \\
\hline Mean VIF & & \\
\hline
\end{tabular}

\section{Copyrights}

Copyright for this article is retained by the author(s), with first publication rights granted to the journal.

This is an open-access article distributed under the terms and conditions of the Creative Commons Attribution license (http://creativecommons.org/licenses/by/4.0/). 